Settling Hebron 
THE ETHNOGRAPHY OF POLITICAL VIOLENCE

Tobias Kelly, Series Editor

A complete list of books in the series is available from the publisher. 


\title{
SETTLING HEBRON
}

\author{
Jewish Fundamentalism \\ in a Palestinian City
}

Tamara Neuman

$\overline{\text { PENN }}$

UNIVERSITY OF PENNSYLVANIA PRESS

PHIL ADELPHIA 
Copyright (C) 2018 University of Pennsylvania Press

All rights reserved. Except for brief quotations used for purposes of review or scholarly citation, none of this book may be reproduced in any form by any means without written permission from the publisher.

$$
\begin{gathered}
\text { Published by } \\
\text { University of Pennsylvania Press } \\
\text { Philadelphia, Pennsylvania 19104-4112 } \\
\text { www.upenn.edu/pennpress }
\end{gathered}
$$

Printed in the United States of America on acid-free paper 13357991086642

\section{Library of Congress Cataloging-in-Publication Data}

Names: Neuman, Tamara, author.

Title: Settling Hebron : Jewish fundamentalism in a Palestinian city / Tamara Neuman.

Other titles: Ethnography of political violence.

Description: 1st edition | Philadelphia : University of Pennsylvania Press, [2018] | Series: Ethnography of political violence | Includes bibliographical references and index.

Identifiers: LCCN 2017049078 | ISBN 9780812249958 (hardcover : alk. paper)

Subjects: LCSH: Jews-West Bank-Hebron. | Land settlementWest Bank-Hebron. | Jewish fundamentalism-West BankHebron. | Hebron-Ethnic relations. | Hebron-in Judaism. Classification: LCC DS110.H4 N48 2018 | DDC 956.94/2—dc23

LC record available at https://lccn.loc.gov/2017049078 